\title{
Mental Capacity Legislation edited by Rebecca Jacob, James Gunn, and Anthony Holland, Second Edition, RCPsych/Cambridge University Press, June 2019, Hardback, ISBN 9781108480369, $£ 29.99$ - CORRIGENDUM
}

Martin Curtice

(C) The Author 2020. This is an Open Access article, distributed under the terms of the Creative Commons Attribution licence (http://creativecommons.org/ licenses/by/4.0/), which permits unrestricted re-use, distribution, and reproduction in any medium, provided the original work is properly cited.

This book review has an error in the title: Mental Capacity Legislation was in fact edited by Rebecca Jacob, Michael Gunn and Anthony Holland. We apologise for the error.

\section{Reference}

1 Curtice M. Mental Capacity Legislation Edited by Rebecca Jacob, James Gunn and Anthony Holland 2nd edn. RCPsych/Cambridge University Press. 2019. £29.99 (hb). 122 pp. ISBN 9781108480369. BJPsych Bulletin 2020; 44(4), 184-184.

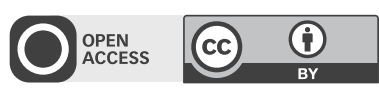

\section{A visual step-by-step guide for clinicians to use video consultations in mental health services: NHS examples of real-time practice in times of normal and pandemic healthcare delivery - ERRATUM}

Gemma Johns, Jacinta Tan, Anna Burhouse, Mike Ogonovsky, Catrin Rees, Alka Ahuja

BJPsych Bulletin (2022) 46, 192-193, doi:10.1192/bjb.2020.144

(c) The Authors 2020. This is an Open Access article, distributed under the terms of the Creative Commons Attribution licence (http://creativecommons.org/ licenses/by/4.0/), which permits unrestricted re-use, distribution, and reproduction in any medium, provided the original work is properly cited. 
In the original published article, country names were missing from the author affiliations. This has now been corrected. services: NHS examples of real-time practice in times of normal and pandemic healthcare delivery. BJPsych Bull 2020; 44(6): 277-84. Available from: https://doi.org/10.1192/bjb.2020.71

\section{Reference}

Johns G, Tan J, Burhouse A, Ogonovsky M, Rees C and Ahuja A. A visual

step-by-step guide for clinicians to use video consultations in mental health

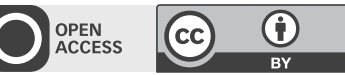

\section{Supporting people in mental health crisis in 21st-century Britain - ERRATUM}

Andrew Molodynski, Stephen Puntis, Em Mcallister, Hannah Wheeler, Keith Cooper

BJPsych Bulletin (2022) 46, 193-193, doi:10.1192/bjb.2020.143

(c) The Authors 2020. This is an Open Access article, distributed under the terms of the Creative Commons Attribution licence (http://creativecommons.org/ licenses/by/4.0/), which permits unrestricted re-use, distribution, and reproduction in any medium, provided the original work is properly cited.

https://doi.org/10.1192/bjb.2019.93, Published online by the Royal College of Psychiatrists, 22 January 2020

In the original published article, country names were missing from the author affiliations. This has now been corrected.

\section{Reference}

Molodynski A, Puntis S, McAllister E, Wheeler H and Cooper K. Supporting people in mental health crisis in 21st-century Britain. BJPsych Bull 2020; 44 (6): 231-32. Available from: https://doi.org/10.1192/bjb.2019.93.

\section{A model for specific goals for in-patient treatment linked to resources and limitations in out-patient treatment - ERRATUM}

Virginia Davies

BJPsych Bulletin (2022) 46, 193-194, doi:10.1192/bjb.2020.142

(c) The Author(s), 2020. This is an Open Access article, distributed under the terms of the Creative Commons Attribution licence (http://creativecommons.org/ licenses/by/4.0/), which permits unrestricted re-use, distribution, and reproduction in any medium, provided the original work is properly cited. 